\title{
EKSISTENSI POS BANTUAN HUKUM DALAM MEMBERIKAN BANTUAN HUKUM DI PENGADILAN AGAMA KELAS I B WATAMPONE
}

\author{
Rosita \\ Sekolah Tinggi Agama Islam Negeri Watampone, Bone, Indonesia \\ e-mail: rosita@gmail.com
}

\begin{abstract}
One of the provision of legal service for the community in court is the establishment of legal aid post. A court legal aid post is a service established by and in any first instance court to provide legal service in the form of legal information, consultation and advice and the creation of required legal documents. The existence of a law courthouse aid post of class IB Watampone is very helpful to the duties of clerks and judges. So that legal service become more effective and efficient. But some obstacles faced by legal aid post in legal services that not cooperative plaintiffs, facilities and minimal infrastructure, and knowledge of legal officers is still lacking.
\end{abstract}

Keywords: Pos Bantuan Hukum, Bantuan Hukum

\section{Pendahuluan}

Salah satu hak yang diberikan oleh peraturan perundang-undangan terkait dengan beracara di pengadilan adalah hak untuk memperoleh bantuan hukum. Hal ini didasarkan pada Pasal 56 UU Nomor 48 Tahun 2009 tentang Kekuasaan Kehakiman yang berbunyi bahwa: (1) Setiap orang yang tersangkut perkara berhak memperoleh bantuan hukum. Dan (2) Negara menanggung biaya perkara bagi pencari keadilan yang tidak mampu.

Ketentuan Pasal 56 UU Nomor 48 Tahun 2009 tersebut merupakan penjabaran dari ketentuan konstitusi negara Republik Indonesia, yakni sesuai dengan yang ditetapkan dalam Pasal 28D ayat (1) UUD 1945 , bahwa setiap orang berhak atas pengakuan, jaminan, perlindungan, dan kepastian hukum yang adil serta perlakuan yang sama di hadapan hukum. Begitu pula yang terdapat dalam Pasal 28 H ayat (2) UUD 1945, bahwa setiap orang berhak mendapat kemudahan dan perlakuan khusus untuk memperoleh kesempatan dan manfaat yang sama guna mencapai persamaan dan keadilan.

Berdasarkan Pasal 28 D, Pasal 28 H UUD 1945 dan UU Nomor 48 Tahun 2009 dapat diketahui bahwa setiap orang berhak dibela/dibantu dan diperlakukan sama di hadapan hukum. Maksudnya, setiap orang yang memiliki masalah hukum berhak untuk menyelesaikan permasalahannya tersebut melalui pengadilan tanpa mengenal status sosial dan tingkat ekonominya. Hal ini sesuai dengan asas equality, bahwa setiap warga negara memiliki persamaan hak dalam proses persidangan, berhak atas perlindungan hukum, dan berhak untuk mendapat perlakuan yang sama dengan semua orang. ${ }^{1}$

${ }^{1}$ Sulaikin Lubis, et al, Hukum Acara Peradilan Agama di Indonesia, (Jakarta: Kencana, 2005), h. 
Berdasarkan teori fiksi dan asas ignorantia legis excusat neminem ${ }^{2}$, maka setiap orang dianggap tahu aturan hukum acara di pengadilan. Namun kenyataannya bahwa tidak setiap orang memiliki kemampuan untuk berbicara di pengadilan. Oleh karena itu, salah satu terobosan hukum yang telah dilakukan oleh pemerintah untuk mengatasi hal ini adalah dengan membentuk Pos Bantuan Hukum (selanjutnya akan disingkat dengan Posbakum). Posbakum merupakan pemberi bantuan hukum secara cuma-cuma yang terdapat pada Pengadilan Negeri, Pengadilan Agama, dan Pengadilan Tata Usaha Negara yang disediakan bagi pencari keadilan yang tidak mampu.

Istilah bantuan hukum merupakan terjemahan dari "legal aid" dan "legal assistance". Istilah legal aid biasanya dipergunakan untuk menunjukkan pengertian bantuan hukum berupa pemberian bantuan hukum berupa pemberian layanan hukum secara cuma-cuma khususnya kepada orang yang tidak mampu, sedangkan legal assistance bermakna pemberian jasa hukum tanpa membedakan keadaan klien pengguna jasa termasuk orang mampu atau tidak. ${ }^{3}$

Sejak tahun 2015 Pengadilan Agama Kelas IB Watampone telah mengadakan Pos Bantuan Hukum yang bertugas memberikan layanan bantuan hukum secara cuma-cuma kepada orang yang tidak mampu dalam bentuk bantuan pembuatan surat gugatan/permohonan, pemberian advis dan konsultasi hukum. Kehadiran Posbakum ini sangat membantu meringankan tugas Pengadilan Agama Kelas IB Watampone khususnya hakim dan panitera.

Berdasarkan latar belakang masalah di atas, maka dirumuskan beberapa permasalahan sebagai berikut: (1) Bagaimana peran Posbakum sebagai pemberi bantuan hukum di Pengadilan Agama Kelas IB Watampone? (2) Bagaimana bentuk pelayanan Posbakum di Pengadilan Agama Kelas IB Watampone? (3) Kendala-kendala apakah yang dihadapi Posbakum dalam melaksanakan tugasnya memberikan pelayanan bantuan hukum di Pengadilan Agama Kelas IB Watampone?

Berdasarkan rumusan masalah, maka tujuan dari penelitian ini adalah: (1) Untuk mengetahui peran Posbakum sebagai pemberi bantuan hukum di Pengadilan Agama Kelas IB Watampone. (2) Untuk mengetahui bentuk pelayanan dan praktik pelaksanaan tugas Posbakum di Pengadilan Agama Kelas IB Watampone. (3) Untuk mengetahui kendalakendala yang dihadapi Posbakum dalam melaksanakan tugasnya memberikan bantuan hukum di Pengadilan Agama Kelas IB Watampone.

Penelitian ini diharapkan memberikan kegunaan baik secara teoritis maupun praktis sebagai berikut:

1. Penelitian ini diharapkan dapat menjadi sumber rujukan bagi peneliti-peneliti lain yang berminat membahas topik yang sama, karena masih sangat kurang dijumpai peneliti yang mengkaji topik ini, bahkan berdasarkan pengetahuan peneliti sampai saat ini belum ada penelitian di STAIN Watampone yang mengkaji mengenai Posbakum.

\footnotetext{
${ }^{2}$ Rusli Effendy, Achmad Ali, dan Poppy Andi Lolo, Teori Hukum, (Ujung Pandang: Hasanuddin University Press, 1991), h.43

${ }^{3}$ Abdurrahman, Aspek-Aspek Bantuan Hukum Di Indonesia, (Yogyakarta: Cendana Press, 1983), h. 
2. Penelitian ini diharapkan dapat menjadi sarana sosialisasi khususnya kepada masyarakat Kabupaten Bone yang umumnya belum mengetahui tentang adanya Posbakum.

Penelitian ini dilaksanakan di Pengadilan Agama Kelas I B Watampone yang terletak di jalan MH. Thamrin, Kecamatan Tanete Riattang, Kabupaten Bone, Provinsi Sulawesi Selatan.

Dalam penelitian ini digunakan jenis penelitian hukum sosiologis atau non doktrinal, yaitu penelitian studi empiris untuk menemukan teori mengenai proses terjadinya dan mengenai proses kerjanya hukum dalam masyarakat. ${ }^{4}$ Dengan kata lain, penelitian ini mengkaji dan menelaah kaidah hukum (das sollen), khususnya ketentuanketentuan hukum yang mengatur mengenai Posbakum di Pengadilan Agama, sekaligus mengkaji dan menelaah implementasinya (das sein) dalam masyarakat. Penelitian ini berguna untuk mengetahui bagaimana aturan hukum itu dilaksanakan termasuk proses penegakan hukum, begitu pula dapat mengungkapkan permasalahan-permasalahan yang ada di balik pelaksanaan dan penegakan hukum. ${ }^{5}$

Data yang digunakan dalam penelitian ini sesuai dengan permasalahan dan tujuan penelitian, dibagi dalam dua jenis data, yaitu:

a. Data primer

Data Primer adalah data yang menjadi bahan dasar dalam melakukan penelitian lapangan yang diperoleh dari jawaban-jawaban yang diberikan oleh narasumber atau data yang diperoleh langsung dari lapangan. ${ }^{6}$ Data primer sebagai data utama diperoleh langsung di lokasi penelitian melalui observasi/pengamatan dan wawancara dengan Ketua Pengadilan, Panitera, dan petugas Posbakum Pengadilan Agama Kelas IB Watampone.

b. Data Sekunder

Data sekunder adalah data yang berfungsi sebagai pelengkap data primer.

Data sekunder diperoleh dari penelusuran berbagai referensi tertulis seperti buku, peraturan perundang-undangan, laporan penelitian, dan dokumen lain yang erat kaitannya dengan masalah yang di bahas dalam penelitian ini.

Adapun teknik pengumpulan data yang digunakan dalam penelitian ini adalah observasi, wawancara,dan dokumentasi/studi kepustakaan. Teknik analisis data dalam penelitian ini adalah analisis data kualitatif, yakni suatu analisis data dengan cara menguraikan dan menginterpresentasikan data yang diperoleh dalam bentuk uraian. Berdasarkan hasil analisis ini dapat diketahui serta diperoleh kesimpulan secara umum yang didasarkan atas fakta-fakta yang diperoleh selama penelitian.

\footnotetext{
${ }^{4}$ Bambang Sunggono, Metodologi Penelitian Hukum, (Jakarta: PT. RajaGrafindo Persada, 2002), h. 43

${ }^{5}$ Amiruddin dan H. Zainal Asikin, Pengantar Metode Penelitian Hukum, (Jakarta: PT. RajaGrafindo Persada, 2004), h. 134-135

${ }^{6}$ Amiruddin dan H. Zainal Asikin, Pengantar Metode Penelitian Hukum, h. 30
} 


\section{Gambaran Umum Posbakum Pengadilan Agama Kelas IB Watampone}

Untuk melaksanakan ketentuan-ketentuan hukum yang tercantum di dalam UU Nomor 48 Tahun 2009, UU Nomor 50 Tahun 2009, dan Peraturan Mahkamah Agung RI Nomor 1 Tahun 2014 yang telah diundangkan maka sejak tahun 2015 Pengadilan Agama Kelas IB Watampone telah membentuk Pos Bantuan Hukum (Posbakum) dengan bekerjasama dengan STAIN Watampone.

Hubungan antara Pengadilan Agama Kelas IB Watampone dan STAIN Watampone mengenai penyelenggaraan Posbakum didasarkan pada perjanjian kerjasama antara Pengadilan Agama Kelas IB Watampone dan STAIN Watampone tentang penyediaan pemberi layanan bantuan hukum pada Pos Bantuan Hukum (Posbakum) Pengadilan Agama Kelas IB Watampone. Perjanjian kerjasama tersebut menetapkan Pengadilan Agama Kelas IB Watampone sebagai pihak pertama dengan hak dan kewajiban sebagai berikut:

1. Menyediakan sarana dan prasarana yang diperlukan untuk Pos Bantuan Hukum, minimal satu ruangan beserta meja dan kursi.

2. Menyediakan anggaran untuk imbalan jasa bagi pemberi bantuan hukum.

3. Membuat jadwal hari dan jam kerja layanan bantuan hukum pada Pos Bantuan Hukum di Pengadilan Agama Kelas IB Watampone.

4. Melakukan pengawasan dan evaluasi terhadap proses layanan bantuan hukum pada Pos Bantuan Hukum di Pengadilan Agama Kelas IB Watampone secara berkala, minimal tiga bulan sekali.

5. Memberi sanksi kepada pihak kedua apabila ternyata melanggar isi perjanjian ini, berupa:
a. Teguran lisan
b. Teguran tertulis
c. Pemberhentian secara sepihak berupa pemutusan hubungan kerjasama ${ }^{7}$

STAIN Watampone sebagai pihak kedua dalam perjanjian kerjasama antara Pengadilan Agama Kelas IB Watampone dan STAIN Watampone memiliki hak dan kewajiban sebagai berikut:

1. Menunjuk petugas pemberi bantuan hukum di Pos Bantuan Hukum dari lembaga bantuan hukum yang dipimpinnya.

2. Melaksanakan pemberian bantuan hukum sesuai hari dan jam kerja yang telah ditentukan.

3. Memerintahkan petugas pemberi bantuan hukum untuk hadir pada hari-hari yang telah ditentukan sesuai dengan jam kerja pada Pengadilan Agama Kelas IB Watampone.

4. Menentukan jumlah petugas pemberi bantuan hukum yang telah ditugaskan di Pos Bantuan Hukum Pengadilan Agama Kelas IB Watampone.

${ }^{7}$ Data dokumen, Perjanjian Kerjasama Antara Pengadilan Agama Kelas IB Watampone dan STAIN Watampone, tahun 2016. 
5. Membuat daftar petugas pemberi bantuan hukum dan sistem pengaturan rotasi para petugas pemberi bantuan hukum, serta mengajukannya ke Ketua Pengadilan Agama Kelas IB Watampone.

6. Berhak mendapatkan fasilitas sarana dan prasaran serta imbalan jasa atas kinerja yang telah dilakukan dari pihak pertama sebagaimana disebutkan pada pasal 4 perjanjian kerjasama ini.

7. Membuat laporan bulanan terkait pelaksanaan tugas pelayanan hukum dan melaporkannya kepada Ketua Pengadilan Agama Kelas IB Watampone.

8. Menyiapkan berbagai sarana pendukung pelaksanaan tugas yang tidak menjadi kewajiban pihak pertama, seperti komputer dan printer. ${ }^{8}$

Posbakum Pengadilan Agama Kelas IB Watampone memiliki empat orang personil. Satu orang menjabat sebagai pembina dengan tugas mengawasi, mengarahkan, dan memberikan petunjuk dan solusi apabila terjadi masalah dalam pembuatan surat gugatan atau permohonan dan pelaksanaan tugas-tugas Posbakum lainnya. Selain Pembina, Posbakum Pengadilan Agama Kelas IB Watampone juga memiliki tiga orang petugas Posbakum yang bertugas memberi layanan bantuan hukum kepada orang tidak mampu berupa membuat surat gugatan atau permohonan, advis, dan konsultasi hukum. Dengan demikian, tiga orang petugas Posbakum tersebut merupakan ujung tombak dari Posbakum Pengadilan Agama Kelas IB Watampone.

\section{Peran Posbakum Sebagai Pemberi Bantuan Hukum di Pengadilan Agama Kelas IB Watampone}

Berdasarkan hasil penelitian yang diperoleh di Pengadilan Agama Kelas IB Watampone diketahui bahwa sebelum terbentuknya Posbakum di Pengadilan Agama Kelas IB Watampone, pada umumnya masyarakat yang akan mengajukan gugatan atau permohonan tidak mengetahui tata cara pembuatan surat gugatan atau permohonan sehingga alternatif yang dipilih adalah meminta bantuan kepada panitera untuk dibuatkan surat gugatan atau permohonan. Hal ini menyebabkan bertambahnya beban kerja bagi panitera. Secara tidak langsung hal ini dapat mempengaruhi kinerja panitera karena waktu kerjanya banyak tersita untuk membuat surat gugatan atau permohonan.

Oleh karena itu dengan terbentuknya Posbakum di Pengadilan Agama Kelas IB Watampone, akhirnya tugas-tugas panitera menjadi lebih ringan. Tugas panitera membantu membuatkan surat gugatan atau permohonan beralih kepada Posbakum. Hal ini sesuai dengan ketentuan Pasal 22 ayat (1) dan Pasal 25 Peraturan Mahkamah Agung RI Nomor 1 Tahun 2014 bahwa Posbakum bertugas memberikan bantuan hukum kepada orang yang tidak mampu berupa pembuatan surat gugatan atau permohonan, memberikan informasi dan konsultasi hukum.

Adapun jumlah dokumen hukum berupa surat gugatan atau permohonan yang telah dibuat oleh Posbakum dalam dua bulan terakhir, sejak September-Oktober 2016 yaitu:

\footnotetext{
${ }^{8}$ Data dokumen, Perjanjian Kerjasama Antara Pengadilan Agama Kelas IB Watampone dan STAIN Watampone, tahun 2016.
} 
Ekspose Volume 16, Nomor 1, Januari - Juni 2017 P-ISSN: 1412-2715, E-ISSN: 2616-4412

Tabel 1

Register Posbakum Pengadilan Agama Kelas IB Watampone bulan September 2016

\begin{tabular}{|c|c|c|c|c|c|c|c|c|c|c|c|c|c|c|}
\hline \multirow{2}{*}{ NO } & \multirow{2}{*}{ HARI } & \multirow{2}{*}{ TANGGAL } & \multicolumn{6}{|c|}{ JUMLAH PEMOHON YANG DILAYANI } & \multicolumn{6}{|c|}{$\begin{array}{c}\text { JUMLAH PEMOHON YANG MASUK } \\
\text { (TERDAFTAR) }\end{array}$} \\
\hline & & & $\begin{array}{r}\text { CERAI } \\
\text { GUGAT }\end{array}$ & $\begin{array}{r}\text { CERAI } \\
\text { TALAK }\end{array}$ & $\begin{array}{l}\text { ISBAT } \\
\text { NIKAH }\end{array}$ & $\begin{array}{c}\text { DISPEN } \\
\text { SASI }\end{array}$ & $\begin{array}{c}\text { WALI } \\
\text { ADHAL }\end{array}$ & PAW & $\begin{array}{r}\text { CERAI } \\
\text { GUGAT }\end{array}$ & $\begin{array}{l}\text { CERAI } \\
\text { TALAK }\end{array}$ & $\begin{array}{l}\text { ISBAT } \\
\text { NIKAH }\end{array}$ & $\begin{array}{c}\text { DISPEN } \\
\text { SASI }\end{array}$ & $\begin{array}{c}\text { WALI } \\
\text { ADHAL }\end{array}$ & PAW \\
\hline $\mathbf{A}$ & $\mathbf{B}$ & $\mathbf{C}$ & D & $\mathbf{E}$ & $\mathbf{F}$ & $\mathbf{G}$ & $\mathbf{H}$ & $\mathbf{I}$ & $\mathbf{J}$ & $\mathbf{K}$ & $\mathbf{L}$ & $\mathbf{M}$ & $\mathbf{N}$ & $\mathbf{O}$ \\
\hline 1 & Kamis & 01/09/2016 & 7 & 2 & 5 & 1 & - & 2 & 5 & 2 & 5 & 1 & - & 1 \\
\hline 2 & Jumat & $02 / 09 / 2016$ & 1 & - & - & - & - & - & 2 & 1 & - & - & - & - \\
\hline 3 & Senin & 05/09/2016 & 10 & 4 & 3 & - & - & - & 7 & 3 & 3 & - & - & - \\
\hline 4 & Selasa & 06/09/2016 & 4 & 1 & 1 & 3 & - & - & 2 & 3 & 1 & 2 & - & - \\
\hline 5 & Rabu & 07/09/2016 & 1 & 3 & - & 2 & - & 1 & 5 & 3 & 1 & 2 & - & - \\
\hline 6 & Kamis & $08 / 09 / 2016$ & 7 & 1 & 1 & 2 & - & 1 & 6 & 2 & - & 2 & - & - \\
\hline 7 & Jumat & $09 / 09 / 2016$ & 1 & 1 & - & 1 & - & - & 1 & 1 & - & 1 & - & - \\
\hline 8 & Senin & $12 / 09 / 2016$ & & & & & & & & & & & & \\
\hline 9 & Selasa & $13 / 09 / 2016$ & 2 & 3 & - & 1 & - & - & 2 & 2 & - & 1 & - & - \\
\hline 10 & Rabu & $14 / 09 / 2016$ & 4 & 2 & 2 & 2 & - & 1 & 3 & 2 & 2 & 2 & - & 1 \\
\hline 11 & Kamis & $15 / 09 / 2016$ & 6 & 5 & - & 1 & - & - & 5 & 3 & - & - & - & - \\
\hline 12 & Jumat & $16 / 09 / 2016$ & 3 & 1 & - & 1 & - & - & 3 & 1 & 1 & - & - & - \\
\hline 13 & Senin & $19 / 09 / 2016$ & 7 & 1 & - & 2 & - & 1 & 4 & 2 & 2 & - & - & 1 \\
\hline 14 & Selasa & $20 / 09 / 2016$ & 7 & - & 4 & - & - & - & 5 & 3 & 4 & - & - & - \\
\hline 15 & Rabu & $21 / 09 / 2016$ & 2 & 1 & - & - & - & 1 & 4 & 1 & 1 & - & - & 1 \\
\hline 16 & Kamis & $22 / 09 / 2016$ & 4 & 2 & - & - & - & - & 5 & 1 & - & - & - & - \\
\hline 17 & Jumat & $23 / 09 / 2016$ & - & - & - & 1 & - & - & - & 1 & - & 2 & - & - \\
\hline 18 & Senin & $26 / 09 / 2016$ & 5 & 1 & 3 & 2 & - & - & 6 & - & 3 & 3 & - & - \\
\hline 19 & Selasa & $27 / 09 / 2016$ & 3 & - & - & 1 & - & - & 1 & - & - & - & - & - \\
\hline 20 & Rabu & $28 / 09 / 2016$ & 1 & - & - & 1 & - & - & - & - & - & - & - & - \\
\hline 21 & Kamis & $29 / 09 / 2016$ & 1 & - & - & - & - & 1 & - & - & - & - & - & - \\
\hline 22 & Jumat & $30 / 09 / 2016$ & - & - & - & - & - & - & - & - & - & - & - & - \\
\hline \multirow{2}{*}{\multicolumn{3}{|c|}{ JUMLAH }} & 76 & 28 & 23 & 17 & - & 8 & 67 & 31 & 23 & 16 & - & 4 \\
\hline & & & \multicolumn{6}{|c|}{152} & \multicolumn{6}{|c|}{141} \\
\hline
\end{tabular}

Sumber: Data dokumen Posbakum Pengadilan Agama Kelas IB Watampone, tahun 2016 
Tabel 2

Register Posbakum Pengadilan Agama Kelas IB Watampone bulan Oktober 2016

\begin{tabular}{|c|c|c|c|c|c|c|c|c|c|c|c|c|c|c|}
\hline \multirow{2}{*}{ NO } & \multirow{2}{*}{ HARI } & \multirow{2}{*}{ TANGGAL } & \multicolumn{6}{|c|}{ JUMLAH PEMOHON YANG DILAYANI } & \multicolumn{6}{|c|}{$\begin{array}{l}\text { JUMLAH PEMOHON YANG MASUK } \\
\text { (TERDAFTAR) }\end{array}$} \\
\hline & & & $\begin{array}{r}\text { CERAI } \\
\text { GUGAT }\end{array}$ & $\begin{array}{l}\text { CERAI } \\
\text { TALAK }\end{array}$ & $\begin{array}{l}\text { ISBAT } \\
\text { NIKAH }\end{array}$ & $\begin{array}{c}\text { DISPEN } \\
\text { SASI }\end{array}$ & $\begin{array}{c}\text { WALI } \\
\text { ADHAL }\end{array}$ & PAW & $\begin{array}{r}\text { CERAI } \\
\text { GUGAT }\end{array}$ & $\begin{array}{r}\text { CERAI } \\
\text { TALAK }\end{array}$ & $\begin{array}{l}\text { ISBAT } \\
\text { NIKAH }\end{array}$ & $\begin{array}{c}\text { DISPEN } \\
\text { SASI }\end{array}$ & $\begin{array}{c}\text { WALI } \\
\text { ADHAL }\end{array}$ & PAW \\
\hline $\mathbf{A}$ & B & $\mathbf{C}$ & D & $\mathbf{E}$ & $\mathbf{F}$ & $\mathbf{G}$ & $\mathbf{H}$ & $\mathbf{I}$ & $\mathbf{J}$ & $\mathbf{K}$ & $\mathbf{L}$ & $\mathbf{M}$ & $\mathbf{N}$ & $\mathbf{O}$ \\
\hline 1 & Senin & $03 / 10 / 2016$ & 6 & - & - & 2 & - & 1 & 9 & 1 & - & 2 & - & 1 \\
\hline 2 & Selasa & $04 / 10 / 2016$ & 6 & 2 & - & - & - & 1 & 10 & 2 & - & - & - & 1 \\
\hline 3 & Rabu & $05 / 10 / 2016$ & 4 & 1 & 1 & - & - & - & 4 & - & 1 & - & - & 1 \\
\hline 4 & Kamis & $06 / 10 / 2016$ & 5 & 2 & 2 & - & - & - & 6 & 1 & 2 & - & - & - \\
\hline 5 & Jumat & 07/10/2016 & 4 & - & - & - & - & - & 5 & - & - & - & - & - \\
\hline 6 & Senin & $10 / 10 / 2016$ & 6 & 2 & 1 & - & - & 1 & 6 & 1 & 1 & - & - & 1 \\
\hline 7 & Selasa & $11 / 10 / 2016$ & 10 & - & 1 & - & - & - & 8 & - & 1 & - & - & - \\
\hline 8 & Rabu & $12 / 10 / 2016$ & 1 & 1 & 2 & 1 & - & 1 & 3 & 1 & 1 & 1 & - & 1 \\
\hline 9 & Kamis & $13 / 10 / 2016$ & 2 & - & 2 & - & - & 1 & 3 & - & 2 & - & - & - \\
\hline 10 & Jumat & $14 / 10 / 2016$ & 6 & - & 2 & 1 & - & - & 3 & - & 2 & 1 & - & - \\
\hline 11 & Senin & $17 / 10 / 2016$ & 10 & 1 & 8 & - & - & - & 7 & 1 & 7 & - & - & - \\
\hline 12 & Selasa & $18 / 10 / 2016$ & 7 & 1 & 6 & 1 & - & - & 9 & 1 & 5 & 1 & - & - \\
\hline 13 & Rabu & 19/10/2016 & 2 & - & 3 & - & - & 2 & 3 & - & 4 & - & - & 2 \\
\hline 14 & Kamis & $20 / 10 / 2016$ & 5 & 2 & 2 & - & - & 1 & 1 & 2 & 1 & - & - & - \\
\hline 15 & Jumat & $21 / 10 / 2016$ & 2 & - & 1 & - & - & - & 5 & - & 1 & - & - & 1 \\
\hline 16 & Senin & $24 / 10 / 2016$ & 6 & 2 & 5 & 2 & - & - & 4 & 2 & 4 & 2 & - & - \\
\hline 17 & Selasa & $25 / 10 / 2016$ & 3 & 1 & 2 & 5 & - & - & 4 & 1 & - & 5 & - & - \\
\hline 18 & Rabu & $26 / 10 / 2016$ & 2 & 2 & 1 & - & - & - & - & - & - & - & - & - \\
\hline 19 & Kamis & $27 / 10 / 2016$ & - & 3 & - & - & - & - & - & - & - & - & - & - \\
\hline 20 & Jumat & $28 / 10 / 2016$ & - & - & - & - & - & - & - & - & - & - & - & - \\
\hline 21 & Senin & $31 / 10 / 2016$ & 5 & - & - & - & - & - & - & - & - & - & - & - \\
\hline \multirow{2}{*}{\multicolumn{3}{|c|}{ JUMLAH }} & 92 & 17 & 39 & 12 & - & 8 & 90 & 13 & 32 & 9 & - & 8 \\
\hline & & & \multicolumn{6}{|c|}{168} & \multicolumn{6}{|c|}{152} \\
\hline
\end{tabular}

Sumber: Data Dokumen Posbakum Pengadilan Agama Kelas IB Watampone, tahun 2016

Berdasarkan tabel 1 dan 2 di atas dapat diketahui bahwa keberadaan Posbakum sangat membantu bagi Pengadilan Agama Kelas IB Watampone, khususnya panitera. Kehadiran Posbakum menciptakan proses berperkara lebih efektif dan efisien khususnya dalam pembuatan surat gugatan dan permohonan. Posbakum Pengadilan Agama Kelas IB Watampone sangat membantu dan senantiasa diperlukan keberadaannya sebagai pemberi layanan hukum bagi orang yang tidak mampu.

\section{Bentuk-Bentuk Pelayanan Posbakum di Pengadilan Agama Kelas IB Watampone}

Pasal 25 Peraturan Mahkamah Agung RI Nomor 1 Tahun 2014 menjelaskan bahwa Posbakum pengadilan memberikan layanan berupa pemberian informasi, konsultasi atau 
advis hukum. Posbakum juga memberikan bantuan pembuatan dokumen hukum yang dibutuhkan seperti surat gugatan atau permohonan.

Berdasarkan hasil penelitian yang diperoleh di Pengadilan Agama Kelas IB Watampone dapat diketahui bahwa ketentuan Pasal 25 diatas telah diimplementasikan dengan baik oleh Posbakum Pengadilan Agama Kelas IB Watampone. Petugas Posbakum secara aktif memberikan bantuan membuatkan surat gugatan atau permohonan. Hal ini dapat dicermati pada tabel 1 dan tabel 2 sebelumnya. Selain itu, petugas Posbakum senantiasa siap memberikan informasi dan konsultasi hukum, seperti persyaratan administrasi yang harus dilengkapi pada saat hendak dibuatkan surat gugatan atau permohonan.

Menurut para petugas Posbakum Pengadilan Agama Kelas IB Watampone, bahwa persyaratan untuk dibuatkan surat gugatan perceraian (cerai talak atau cerai gugata) adalah melampirkan fotocopy KTP penggugat atau pemohon, buku nikah asli/duplikat, surat izin cerai dari atasan bagi penggugat atau pemohon yang berstatus PNS, dan yang bermohon harus yang bersangkutan /tidak dapat diwakilkan.

Persyaratan administrasi untuk permohonan pengesahan nikah adalah fotocopy KTP pemohon, fotocopy keterangan kematian jika salah satunya meninggal, fotocopy SK terakhir jika yang meninggal PNS/pensiunan, fotocopy kartu keluarga pemohon, fotocopy kartu tanggungan dalam daftar gaji.

Persyaratan administrasi untuk permohonan dispensasi kawin adalah fotocopy KTP orang tua calon mempelai, fotocopy buku nikah orang tua calon mempelai/kartu keluarga, fotocopy akta kelahiran/ijazah kedua calon mempelai/kartu keluarga, surat penolakan dari KUA.

Persyaratan administrasi untuk permohonan wali adhal adalah fotocopy KTP yang bersangkutan, surat dari KUA tempat akan menikah bahwa adanya halangan atau kekurangan persyaratan untuk menikah, penolakan pernikahan dari KUA tempat akan menikah, dan surat pengantar dari kepala desa/kelurahan. Persyaratan administrasi permohonan hak asuh anak (hadhanah) adalah fotocopy akta nikah/akta cerai dan fotocopy akta kelahiran

Persyaratan permohonan poligami adalah fotocopy KTP pemohon, fotocopy akta nikah, surat pernyataan rela dimadu yang ditandatangani oleh isteri pertama, surat pernyataan berlaku adil ditandatangani oleh pemohon, surat pernyataan rela dimadu yang ditandatangani oleh calon isteri, surat keterangan penghasilan yang ditandatangani oleh desa/lurah/bendahara/jika PNS/pegawai swasta, fotocopy akta cerai jika calon isteri kedua janda cerai, dan daftar harta bersama isteri pertama.

Persyaratan permohonan penetapan ahli waris adalah foto copy KTP para ahli waris, surat keterangan kematian dari desa/lurah, surat keterangan ahli waris dari desa/lurah, silsilah keluarga dalam bentuk bagan ditandatangani oleh kepala desa/kelurahan dimulai dari orang tua yang meninggal dunia, fotocopy kartu keluarga yang meninggal, fotocopy buku nikah jika yang meninggal telah menikah, fotocopy print out buku tabungan terakhir/nomor porsi/sertifikat tanah bukti kepemilikan harta benda, identitas para pemohon, dan fotocopy SK terakhir jika yang meninggal dunia PNS/pensiun. 
Berdasarkan Pasal 3 huruf a dan Pasal 22 ayat (1) dan (2) Peraturan Mahkamah Agung Nomor 1 Tahun 2014 pihak-pihak yang dapat menerima pelayanan bantuan hukum di Posbakum adalah orang-orang yang tidak mampu secara ekonomi. Syarat administrasi untuk menerima layanan bantuan hukum Posbakum adalah membawa surat keterangan tidak mampu dari kepala desa/kelurahan tempat tinggalnya. Apabila tidak ada dapat diganti dengan surat keterangan lain yang menjelaskan tentang ketidakmampuan ekonominya tersebut. Apabila semua surat-surat tersebut juga tidak ada maka dapat digantikan dengan surat pernyataan tidak mampu membayar jasa advokat.

Praktek pelaksanaan pemberian bantuan hukum di Posbakum Pengadilan Agama Kelas IB Watampone ternyata tidak hanya memberikan bantuan hukum kepada orangorang yang tidak mampu secara ekonomi tetapi juga memberikan bantuan hukum kepada orang-orang yang mampu. Hal ini berdasarkan pada hasil wawancara dengan salah seorang petugas Posbakum bahwa apabila orang yang akan meminta bantuan hukum Posbakum tidak memiliki surat keterangan tidak mampu atau surat keterangan lainnya, sekalipun pencari keadilan tersebut berstatus PNS atau karyawan swasta, Posbakum tetap akan melayani karena pelayanan yang diberikan bukan hanya untuk yang tidak mampu dalam hal materi tapi juga memberikan pelayanan hukum bagi yang tidak mengetahui membuat surat gugatan atau permohonan. Tidak ada persyaratan khusus untuk mendapatkan bantuan hukum Posbakum. Semua yang berperkara di Pengadilan Agama Watampone mendapatkan pelayanan dari Posbakum, kecuali dalam perkara pembagian warisan. Semua orang yang berpekara di Pengadilan Agama akan dilayani oleh Posbakum kecuali ia menggunakan jasa advokat/pengacara.

Berdasarkan uraian diatas dapat disimpulkan bahwa Posbakum Pengadilan Agama Kelas IB Watampone memberikan pelayanan bantuan hukum kepada orang-orang yang tidak mampu. "Tidak mampu" diartikan oleh pihak Pengadilan Agama Kelas IB Watampone sebagai tidak mampu dari segi ekonomi (orang miskin) dan tidak mampu/tidak memiliki pengetahuan hukum untuk membuat surat gugatan atau permohonan.

Bantuan yang diberikan oleh Posbakum Pengadilan Agama Kelas IB Watampone saat ini hanya dilaksanakan pada tingkat pertama dan sebatas memberikan informasi dan konsultasi hukum serta pembuatan surat gugatan atau permohonan. Posbakum Pengadilan Agama Kelas IB Watampone belum memberikan bantuan hukum dalam pembuatan surat jawaban, surat replik dan surat duplik.

\section{Kendala-Kendala yang Dihadapi Posbakum Dalam Memberikan Pelayanan Bantuan Hukum di Pengadilan Agama Kelas IB Watampone}

Hal-hal yang sering menjadi kendala bagi Posbakum Pengadilan Agama Kelas IB Watampone dalam melaksanakan tugasnya memberikan bantuan hukum kepada masyarakat yang tidak mampu adalah sikap tidak kooperatif dari sebagian penggugat atau pemohon. Penggugat atau pemohon kadang memberikan keterangan yang berbelit-belit dan tidak jujur pada saat memberikan informasi/tahap wawancara dengan petugas Posbakum. Misalnya, dalam perkara permohonan penetapan ahli waris, pemohon kadang tidak jujur menyampaikan keberadaan ahli waris yang lain yang berada di luar negara 
Indonesia. Jadi pemohon tidak memberitahukan identitas semua orang yang termasuk ahli waris. Kadang pula penggugat atau pemohon memberikan uraian peristiwa/duduk perkara secara tidak lengkap.

Kendala lain yang dihadapi oleh petugas Posbakum Pengadilan Agama Kelas IB Watampone adalah penggugat atau pemohon sering membantah atau menolak isi surat gugatan atau permohonan yang telah dibuatkan oleh petugas Posbakum di dalam persidangan. Penggugat atau pemohon menganggap bahwa isi surat gugatan atau permohonan tidak sesuai dengan keterangan yang telah disampaikan oleh penggugat atau pemohon kepada petugas Posbakum pada saat tahap wawancara. Hal ini menyebabkan petugas Posbakum sering dipanggil oleh majelis hakim yang menangani perkara tersebut untuk mengklarifikasi hal tersebut.

Padahal berdasarkan hasil penelitian mengenai tahap-tahap pembuatan surat gugatan atau permohonan oleh petugas Posbakum yang telah dipaparkan sebelumnya, salah satu tahap yang harus dilakukan adalah penggugat atau pemohon harus membaca dan memahami isi surat gugatan atau permohonan yang telah dibuat oleh petugas Posbakum. Apabila penggugat atau pemohon telah menyetujui isi surat gugatan atau permohonan tersebut, maka selanjutnya surat tersebut ditandatangani oleh pengugat atau pemohon di hadapan petugas Posbakum.

Berdasarkan hasil penelitian di Pengadilan Agama Kelas IB Watampone diketahui bahwa Pengadilan Agama Kelas IB Watampone telah menyediakan tempat bagi Posbakum bergabung dengan ruangan pendaftaran perkara. Adapun sarana lain yang diberikan adalah meja, kursi, printer satu unit, dan alat tulis kantor.

Menurut peneliti, sarana dan prasana yang disediakan bagi Posbakum masih sangat minim. Seharusnya Posbakum memiliki ruangan tersendiri sehingga orang-orang yang hendak meminta bantuan hukum ke Posbakum dapat menyampaikan masalahnya dengan tenang dan nyaman. Mengenai pengadaan komputer untuk Posbakum sampai saat ini belum ada sehingga tiga orang petugas Posbakum harus membawa dan memakai laptop pribadi masing-masing untuk melaksanakan tugasnya.

Posbakum Pengadilan Agama Kelas IB Watampone saat ini hanya membuat dokumen hukum untuk perkara perceraian (pengesahan nikah, dispensasi kawin, wali adhal, hak asuh anak (Hadhanah), poligami, dan penetapan ahli waris. Posbakum Pengadilan Agama Kelas IB Watampone belum diperkenankan untuk membuat surat gugatan untuk sengketa kewarisan dan sengketa-sengketa lainnya yang terkait dengan kebendaan. Apabila ada orang yang hendak dibuatkan surat gugatan untuk sengketasengketa tersebut, maka akan dianjurkan ke advokat. Hal ini disebabkan karena menurut Panitera Pengadilan Agama Kelas IB Watampone bahwa petugas Posbakum belum dipercayakan membuat surat gugatan untuk sengketa kewarisan dan sengketa kebendaan lainnya karena biasanya perkaranya rumit dan pengetahuan hukum petugas posbakum masih diragukan untuk itu. 


\section{Simpulan}

Keberadaan Posbakum di Pengadilan Agama Kelas IB Watampone sangat membantu bagi hakim dan panitera khususnya dalam pembuatan surat gugatan atau permohonan. Sebelumnya panitera yang bertugas membantu membuatkan surat gugatan atau permohonan, namun dengan terbentuknya Posbakum di Pengadilan Agama Kelas IB Watampone tugas-tugas panitera tersebut beralih kepada Posbakum. Adapun Bentuk pelayanan Posbakum Pengadilan Agama Kelas IB Watampone telah sesuai dengan ketentuan Peraturan Mahkamah Agung Nomor 1 Tahun 2014. Dalam melaksanakan tugasnya, Posbakum telah memberikan pelayanan bantuan hukum berupa informasi dan konsultasi hukum serta membuatkan surat gugatan dan permohonan kepada orang-orang yang tidak mampu. Kemudian Posbakum Pengadilan Agama Kelas IB Watampone masih menghadapi masalah dalam melaksanakan tugasnya, antara lain penggugat atau termohon yang tidak kooperatif, tidak jujur, dan berbelit-belit dalam menguraikan keterangan, kurangnya sarana dan prasaranan, dan pengetahuan hukum kewarisan para petugas Posbakum yang masih kurang.

\section{Daftar Pustaka}

Abdurrahman, Aspek-Aspek Bantuan Hukum Di Indonesia, Cet. 1; Yogyakarta: Cendana Press, 1983

Amiruddin dan H. Zainal Asikin, Pengantar Metode Penelitian Hukum, Jakarta: PT. RajaGrafindo Persada, 2004

Effendy, Rusli, Achmad Ali, dan Poppy Andi Lolo, Teori Hukum, Ujung Pandang, : Hasanuddin University Press, 2003

Lubis, Sulaikin, et al, Hukum Acara Peradilan Agama di Indonesia, Jakarta: Kencana, 2005

Perjanjian Kerjasama Antara Pengadilan Agama Kelas I B Watampone dan STAIN Watampone, 2016

Sunggono, Bambang, Metodologi Penelitian Hukum, Jakarta: PT. RajaGrafindo Persada, 2002 